\title{
Open for business? Effects of Los Angeles Metro Rail construction on adjacent businesses
}

\author{
Rosalie Ray \\ Columbia University \\ rsr2150@columbia.edu
}

\begin{abstract}
Recent court cases and news reports have focused on the effects of transit construction on business revenue and survival, yet the topic is underexplored in the scholarly literature. This paper examines whether transit construction negatively affected the revenue and survival of businesses along the second segment of the Los Angeles Metro Rail Red Line under Vermont and Hollywood Boulevards. Using National Establishment Time-Series business data, the research shows that business survival was significantly lower among businesses within 400 meters of stations, where cut and cover construction was used. A difference-in-differences technique was employed to determine whether revenue loss was the main mechanism by which businesses were displaced, but revenue loss was not found to be significant. The increased failure rate provides evidence that construction effects of mitigation programs for businesses should be standard practice when building new transit lines. Further research and data collection on business tenure are needed to understand the dynamics of business displacement around transit and to make such programs more effective.
\end{abstract}

\section{Article history:}

Received: August 17, 2016

Received in revised form: April

24, 2017

Accepted: May 1, 2017

Available online: July 27, 2017

\section{Introduction}

Planners and politicians sell major transit investments with the dual promise of 1) providing residents and businesses with better access and 2) transforming corridors through economic development. The dual promise includes an inevitable tension: The improved access only benefits those who remain after the transformation. The pressures of construction and rising rents from increases in property values spurred by the new transit project can put establishments out of business. In some cases, transit planners desire such business turnover; for example, replacing auto-oriented businesses with street-facing retail is often seen as an improvement. In others, local communities end up harboring resentment over the destruction of commercial corridors or a transformation that leaves them behind.

When planning a transit corridor, what is the responsibility of the planner to the corridor businesses? This question has largely been absent from planning scholarship, though of pressing importance to local businesses and planners working in community outreach for projects (Fan \& Guthrie, 2013). Most of the planning literature on transit and commercial property has discussed rising property values as an unquestioned benefit and dismissed losses due to construction as temporary costs outweighed by

Copyright 2017 Rosalie Ray

http://dx.doi.org/10.5198/jtlu.2017.932

ISSN: 1938-7849 | Licensed under the Creative Commons Attribution - Noncommercial License 3.0

The Journal of Transport and Land Use is the official journal of the World Society for Transport and Land Use (WSTLUR) and is published and sponsored by the University of Minnesota Center for Transportation Studies. 
the permanent benefits of improved access. Yet for the businesses that close before seeing the benefits, the cost is permanent. Moreover, in the case where the business serves a social role in the community, the cost of failure spreads beyond the business owner (Oldenburg, 1999; Fujioka, 2011; Zukin et al., 2009).

Responding to these concerns, planners have begun to implement construction mitigation programs aimed at helping businesses survive the transition. Programs vary considerably, and there is currently no planning research to use when developing a program. This paper takes a step toward filling that gap by evaluating the survival rate on an older transit project, the second segment of the Red Line in Los Angeles, and by exploring one potential mechanism of business failure, the loss of revenue due to construction nuisance. It finds that revenue loss does not appear to be the main mechanism of business failure and suggests that other factors such as rising rents may be more salient. The paper begins with a review of the current literature and then discusses the local case before presenting the methodology for the quantitative study and results. It concludes with a discussion of the policy implications.

\section{The two headwinds against survival: Construction nuisances and rising property values}

Businesses on corridors slated for transit construction face two headwinds, one temporary and one longlasting. The first is the effect of construction on revenue through lost access, loss of parking (temporarily for staging or long-term), water and electricity service interruptions, and experiential nuisances like dust and noise. The second is the rise in property values, if the business is renting its space. Rising land values are benefits to owners, but rent increases in expectation of rising land values force businesses to adapt or exit, and not all sectors or business structures are equally able to survive such churn. This section first discusses the literature on small business survival in general and then research on each headwind.

\subsection{Small business survival}

For much of the twentieth century, the conventional wisdom was that four out of five firms fail within the first five years. In 1989, the U.S. Small Business Administration (SBA), using the Dun and Bradstreet business data that forms the basis for this research, found that in fact, it was closer to three out of five, or a 60 percent failure rate (Phillips \& Kirchhoff, 1989). Everett and Watson (1998) delineate the risks faced by small businesses as economy risks, industry risks, and firm risks; firms are vulnerable to changes in the broader economy and in their particular sector as well as to the risks they can control within the firm. A number of economists have looked at the firm-level risk factors (Evans, 1987; Phillips \& Kirchhoff 1989; Bates \& Nucci, 1989; Bates, 1990; Headd, 2003) and reached a consensus that firm size, age, and sector are major factors in survival, as well as owner education and size of owner financial investment. Unsurprisingly, older, larger firms not in retail or construction owned by well-educated people with high financial capacity tend to survive longer than their counterparts.

Retail firms are particularly prone to closure because they have the fewest barriers to entry, which can test a business's likelihood of survival before opening. They require little in capital other than initial stock and shelves, unlike restaurants or manufacturing, and the proprietor needs no degree, unlike many services. They are also more vulnerable to construction nuisances because they rely on street traffic and spur of the moment decision-making. Tenure is an issue as well, as many retail establishments operate with shorter leases than more capital-intensive sectors like restaurants (Benjamin, Boyle, \& Sirmans, 1990; Main, 1989). Wholesale establishments face similar obstacles, though they are somewhat less vulnerable to construction nuisance as they rely less on street traffic. 


\subsection{Transit construction}

Regarding the first headwind, there are no peer-reviewed studies on the effects of transit construction activity on business revenue or survival during construction. One study in a law journal identifies four successful mitigation programs in Portland, Seattle, Minneapolis-St. Paul, and Phoenix, but does no assessment of the relative effectiveness of various programs (Richardson, 2014). There is also a small body of literature on construction effects from highway rehabilitation (e.g., De Solminihac \& Harrison, 1993; Harrison \& Waldman, 1998; Young, Wolffing, \& Tomasini, 2005). The most detailed of those studies, which broke down effects by sector, found that those businesses for which there were substitutes off the corridor, like home furnishings stores, food stores, and general merchandise, suffered the most (De Solminihac \& Harrison, 1993).

Three transit agencies tracked business closures during construction as part of their mitigation program. Their evidence suggests that effects vary widely, though the studies did not take into account broader economic trends within and among cities during construction. The most recent estimates from the Minneapolis-St. Paul Central Corridor project show a net 2\% loss of businesses in areas surrounding the corridor, though there was a net increase of 11 businesses fronting the rail line directly (Tigan, 2014). Among the subset of corridor businesses that applied for loans from a mitigation program, revenue losses were between two and 84 percent (Metropolitan Council \& FTA, 2013). Seattle found no loss of businesses during Central Link construction, though roughly one out of every ten relocated off the corridor and were replaced by new business. Approximately 180 businesses used the locally funded mitigation resources (Krieg, 2009).

TriMet in Portland, OR, was the first agency to systematically track businesses during construction. They identified only three businesses out of 106 that closed or relocated during construction of their Interstate Avenue light rail line (Houston Tomorrow, 2006). During construction, TriMet provided both loans and technical assistance, with much higher take-up rates for technical assistance. TriMet tracked participation by minority businesses in particular and found that they were the majority of beneficiaries in both programs (Agnew et al., 2010). Taken together, the three projects suggest that effects are highly variable across cities, and more research is needed to understand both the potential impacts and the value of particular mitigation activities.

\subsection{Rising property values}

As for the second headwind, there is considerable literature about the effect of transit on property values, both residential and commercial (see Debrezion, Pels, and Rietvald, 2007; Mohammad et al., 2013; and Higgins and Kanaroglou, 2016, for good summaries). All three reviews note that the local context matters for the effect of transit on property values. Mohammad et al (2013) and Higgins and Kanaroglou (2016) conclude that less dense, more car-oriented cities and regions see less of an effect on property values than denser, transit oriented cities and that zoning and other local land use policies matter to the extent that they can either encourage or prevent redevelopment. Zhang et al. (2014) show that the strength of the effect also varies by mode, with heavy rail having a greater effect than light rail. Debrezion, et al. (2007) find that commercial property sees more of an effect than residential property but the effect is more concentrated around the station, though Nelson et al. (2015) argues that in the case of Dallas, TX, commercial property premiums extend nearly $3 \mathrm{~km}$.

Property value studies generally use hedonic pricing, increasingly as part of a spatial lag model (e.g., Wang et al., 2016; Xu et al., 2016) or a before and after comparison using repeat sales (Chatman, Tulach, and Kim, 2012; Kim and Lahr, 2014; Dubé et al., 2011, 2013). A few studies use a differencein-differences quasi-experimental model to account for unobservable characteristics (Bajic, 1983; Gib- 
bons and Machin, 2005; Dubé et al., 2011, 2013; Mohammad et al., 2017). This research builds off the quasi-experimental work, identifying a control group and testing the treatment effects of transit construction on businesses.

A growing number of studies have linked rising residential property values to gentrification. Lin (2002) used property values explicitly as his indicator of gentrification in Northwest Chicago. Looking at three Canadian cities, Grube-Cavers and Patterson (2015) found evidence of gentrification following transit via property values in Toronto and Montreal though not in Vancouver, which they explained by the relatively young age of the city's rapid transit system. Kahn (2007) found that new "walk and ride" transit stations resulted in increases in adjacent home prices and the share of nearby residents with a college education, and Zheng and Kahn (2013) found that transit-associated gentrification was also present in Beijing. That research looked at the related effects on retail and found that popular chain restaurants follow transit expansion.

Two studies extended the transit-induced gentrification discussion to explore residential displacement (Pollack, Bluestone, and Billingham, 2010; Dominie, 2012). Both found increases in incomes and in the share of residents who drove around station areas. Pollack, et al. (2010) note that the process of gentrification is more complex than they first envisioned; they had expected greater displacement but found that while many older residents are not displaced, the change in the retail mix still affects their sense of community within the neighborhood as former gathering places go out of business.

There is growing research on commercial gentrification and its relationship to neighborhood change. Koebel (2014) found that property and location characteristics (like the presence of a revitalization project or, though not explored, new transit construction) had an effect on neighborhood retail composition independent of and more significant than changes in neighborhood demographic characteristics. Meltzer and Schuetz (2012) looked at New York City zip codes and found that low-income neighborhoods had less diverse retail mixes, a lower density of retail, and a smaller average establishment size, which meant that when gentrification occurred, it rapidly improved retail access. Like Chapple and Jacobus (2008), however, they found that retail expanded faster in already middle- or high-income neighborhoods.

The project closest to this research is Schuetz (2015), which analyzed retail change near new transit stations in four California metropolitan areas. Schuetz used a modified difference-in-differences with two control groups (older stations and areas farther from the stations) to measure the effect of transit station openings on retail employment density. The dependent variable was taken from the same dataset as this work, the National Establishment Time Series. Schuetz found that new stations were not significantly associated with increased retail employment and, in fact, retail activity decreased around downtown intra-metropolitan stations, though the change was insignificant in Los Angeles. Her findings of decreased retail employment density provide further evidence for both the heightened vulnerability of retail and the potential mechanism of loss. This research differs from Schuetz by focusing on the period during construction instead of after opening. The fact that Schuetz finds a loss in retail employment density after station opening suggests that the main mechanism of business failure persists after transit construction, and thus is likely not construction nuisance related, consistent with the findings of this paper.

\section{$3 \quad$ Building the Red Line in Hollywood}

The Metro Rail Red Line runs from Union Station in downtown Los Angeles to the San Fernando Valley via Hollywood (See Figure 1). The subway line was constructed in three phases, moving west and north from downtown Los Angeles. The first segment, from Union Station to Westlake/MacArthur 
Park, opened in 1993. The second segment, running from the Wilshire/Vermont Station to the Hollywood/Highland Station, began construction in 1992 and opened for revenue service in the summer of 1999. The final segment, from Hollywood to the San Fernando Valley, opened in 2000. Tunnels were built with tunnel-boring machines while the stations were built using cut and cover construction. Cut and cover construction causes more disruption to surrounding businesses because the road and sidewalk surfaces are disturbed, restricting access to autos and pedestrians.

This paper focuses on the second segment, Minimum Operating Segment 2, from Wilshire/Vermont to Hollywood/Highland. Local politicians clashed considerably about the segment and ended up with a route that was as much about political power as it was about need for access (Taylor, Kim, \& Gabhauer, 2009). Rather than going down the dense Wilshire Boulevard corridor, the route goes north along Vermont Avenue and west on Hollywood Boulevard to Highland Avenue. Previous studies on the corridor found increases in property values before construction began (Fejarang, 1993) but declines in commercial property value just as the stations opened (Cervero \& Duncan, 2002). Declines in commercial property value are also consistent with Schuetz's (2015) finding of decreased retail employment density after stations opened. More recently, Kahn (2007) found little evidence of gentrification based on changes in household income between 1970 and 2000, though he did note an increasing share of college-educated residents. As a counter to Kahn's findings, Dominie (2012) found that residents in station areas took fewer transit trips than before the rail line opened, which he attributes to a decline in low-income transit dependent populations around stations. 


\section{Metro Rail \& Busway}

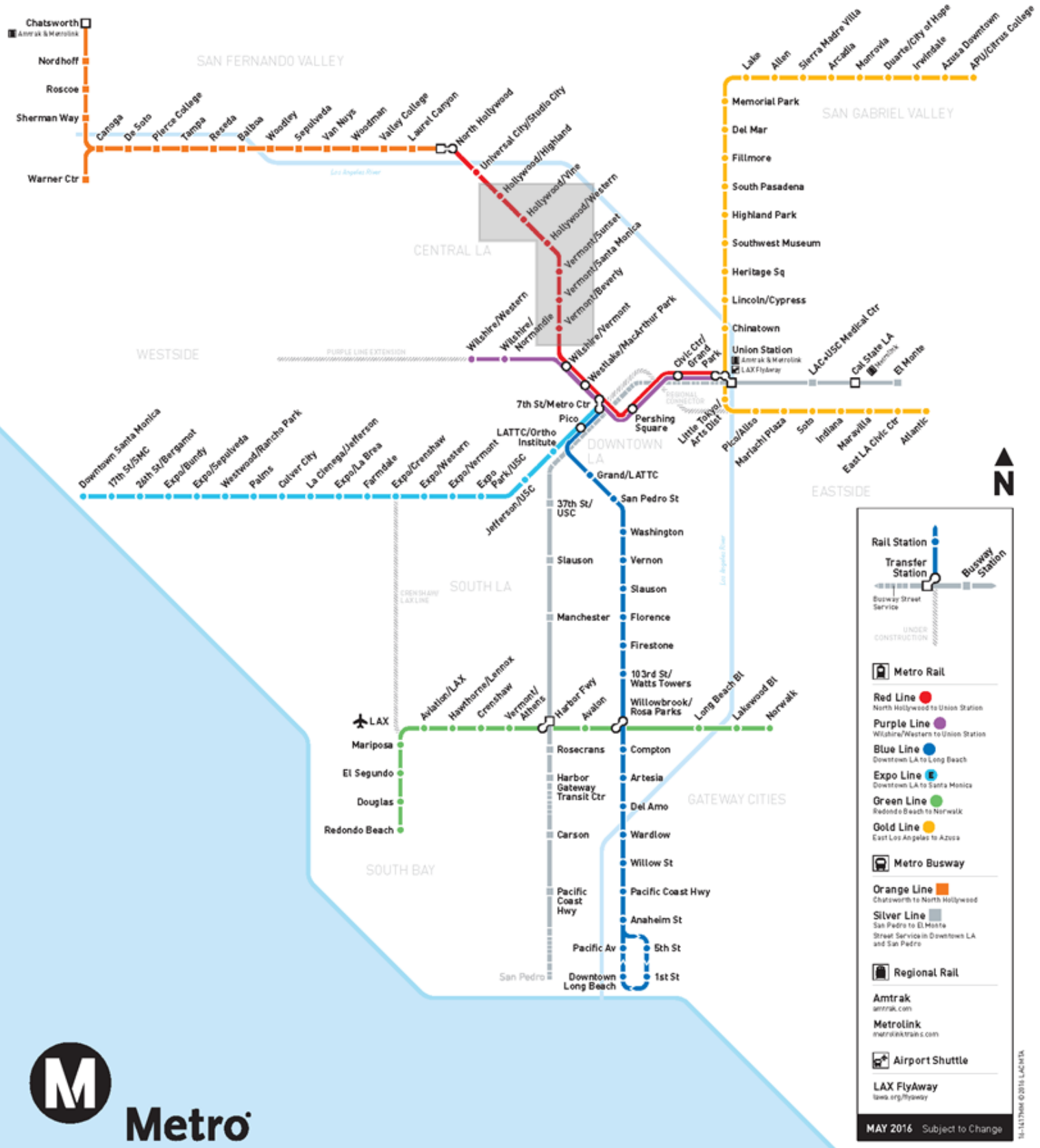

Figure 1: Los Angeles metro system map with study area highlighted 
Given the discrepancy between Kahn (2007) and Dominie (2012), this research began by assessing the census tract data for the stations. Between 1990 and 2010, the overall population declined or remained stable, and the groups leaving the area were disproportionately minority and low-income. The four northern stations, from Hollywood/Highland to Vermont/Sunset, have historically been wealthier and Whiter than Vermont/Santa Monica and Vermont/Beverly and the divide widened slightly between 1990 and 2010. Vermont/Sunset and Hollywood/Vine switched from being plurality Hispanic to plurality White. Rather than the traditional idea of gentrification as an influx of wealthier people into blighted areas, the northern stations are seeing increases in income and growth in the share of nonHispanic White residents alongside an overall decline in population. The decline in overall population implies this was the result of outmigration of Hispanics rather than in-migration of Whites, suggesting displacement. The data indicate that gentrification may be occurring along the Hollywood Boulevard section of the corridor but not quite in the way the popular image of gentrification would imply.

There was a mitigation program put in place for the four northern stations, unique among the early rail lines constructed in Los Angeles. The boundaries of the program were set by the benefit assessment districts that were established to contribute to construction costs, though the assessments were never made (Drew, 1996; Mathur \& Smith, 2012). The mitigation program differed significantly from the types of mitigation programs described above. No money could be given or loaned directly to businesses, so money was instead spent on street cleaning, private security, and occasional parties along Hollywood Boulevard. Using the coarse-grained data available for this current research, no statistically significant difference between program stations and non-program stations was revealed, so the distinction was not carried through the analysis.

\section{$4 \quad$ Research methodology}

This paper conceptualizes transit construction and station construction as treatments applied to surrounding businesses. Businesses along Vermont Avenue and Hollywood Boulevard were "treated," while others (a control group) in the surrounding area were not. Determining the effect of the treatment requires overcoming two obstacles: the missing observation of the counterfactual and the nonrandom assignment of treatment. One cannot directly observe a business under both treated and untreated conditions. As a result, instead of generating an individual causal effect from each business, the estimate is an average treatment effect that represents the difference between untreated and treated populations.

Defining the control population is thus of primary importance. A considerable portion of the property value research concerns determining the spatial extent of the treatment effect of transit on nearby businesses, with estimates ranging from 152 meters (Falcke, 1978, cited in Higgins \& Kanaroglou, 2016) for retail and office rents in Oakland to $3 \mathrm{~km}$ for office rents in Dallas. (Nelson et al., 2015). Though Los Angeles, like Dallas, is car-oriented, the neighborhood in which the subway was constructed is one of the denser areas in the city, and thus the $3 \mathrm{~km}$ estimate is less applicable. Debrezion, Pels, and Rietvald (2007) find that the strongest effect on commercial property is within 400 meters, which is also the metric used by Schuetz (2015) and Weinstein and Clower (1999). While Shuetz's treatment ends at 400 meters, she takes the further precaution of setting her control group between 800 meters and 4.8 kilometers.

Mohammad et al. (2017) uses multiple rings at $0.5 \mathrm{~km}, 1 \mathrm{~km}$, and $1.5 \mathrm{~km}$ to ensure that control group selection does not bias the results. Each model is run with a different ring, such that the control group changes with each model. In the first model, the control group is any property farther than 0.5 $\mathrm{km}$, in the second, farther than $1 \mathrm{~km}$, and so forth.

This paper adopts the multiple rings method from Mohammad et al. (2017) but lessens the initial distance. The shorter distances reflect the paper's focus on construction rather than property values. The 
immediate construction effects of dust, noise, and lost access are felt more strongly by those fronting the street under construction and to a lesser extent on those by the side streets. Thus, the paper uses a very narrow initial ring of 150 meters and then builds out to 305 meters, 400 meters, and 800 meters. These buffers cover the lower end of Mohammad et.al. (2013)'s impact range, at 400-800 meters. Mohammad et.al. (2013) noted that studies saw effects up to 1200 meters, but the focus on construction impacts and the density of the neighborhood argue for the narrower impact band.

The inner boundary of the control area for each model is set by the bands as in Mohammad et al. (2017), with the control group at 150 meters including all businesses farther than 150 meters from the station, that at 400 meters including all businesses farther than 400 meters, and so forth. For all models, the outer boundary of the control area is represented by the extent of all ZIP codes within 800 meters of a station (Figure 2). The control area approximates the $4.8 \mathrm{~km}$ extent used in Schuetz (2015) while excluding the downtown areas, which have a different business environment.

Location along a corridor and location near a station were tested separately because the tunneling used tunnel boring machines while the stations employed cut-and-cover construction. The rail corridor buffers were 60 meters from the subway line (straight-line distance measured from the MTA Red Line shapefile), roughly twice the width of the street, and 400 meters, the most common boundary used in the literature. After running regressions with both rail buffers, the $60 \mathrm{~m}$ buffer carried more explanatory power, so the $400 \mathrm{~m}$ buffer was dropped. 


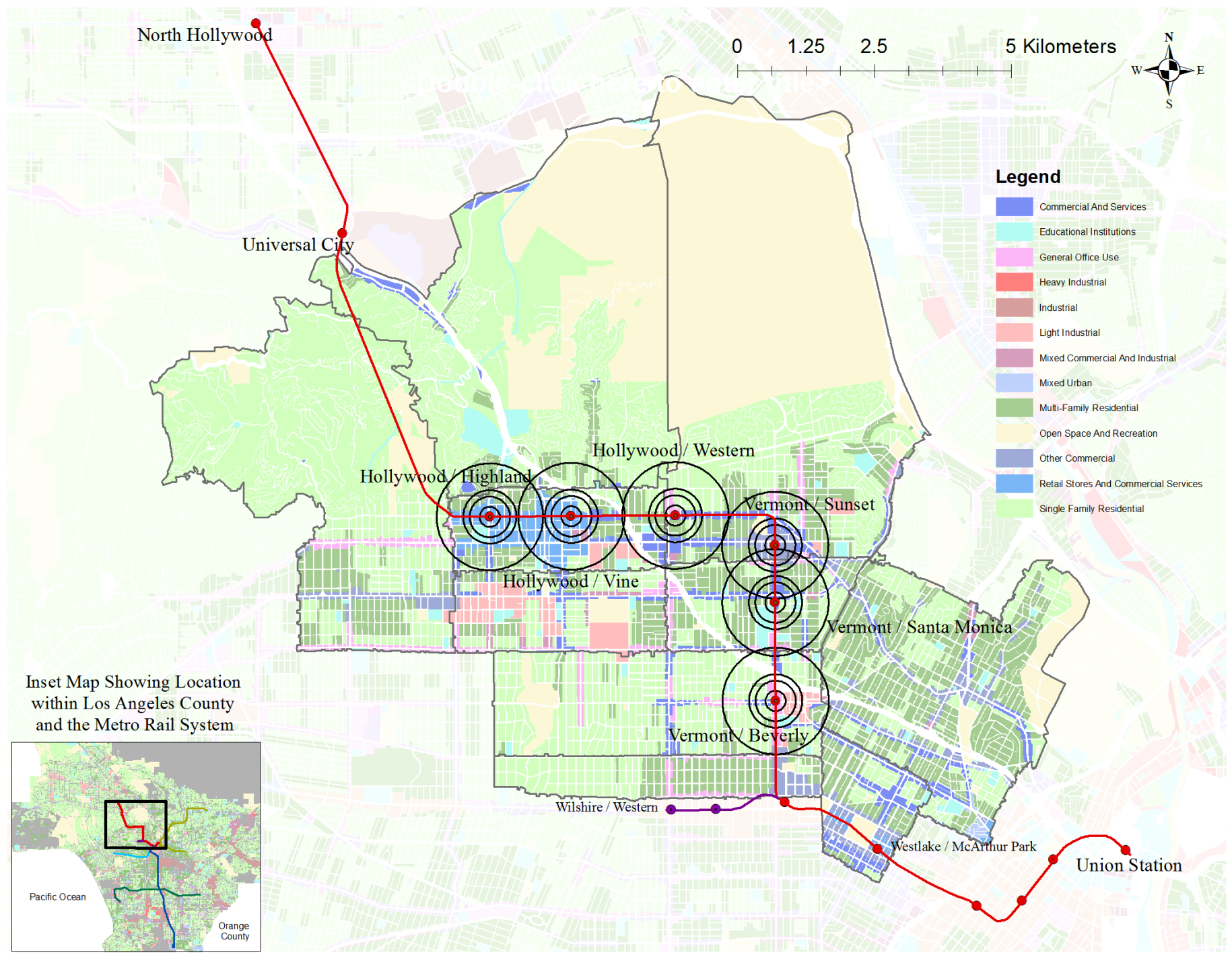

Figure 2: Showing land use, control area boundaries, and 150-meter, 305-meter, 400-meter, and 800-meter buffers

Nonrandom assignment requires controls for confounding effects, variables that may influence both the decision to treat (why a station was placed where it was) and the potential outcomes (survival and revenue effects during construction). In this study, employment and business type are used to control for confounding effects. As noted above, size and sector are major determinants of survival (Evans, 1987; Bates \& Nucci, 1989; Phillips \& Kerchoff, 1989). Size and sector may also affect station location, as larger businesses or business types with higher traffic generate more demand for transit.

Compared to the control area, station locations have much larger businesses, though the sector mix is roughly the same. Table 1 shows the composition of each. Each column is mutually exclusive of the others. Other than within the ring directly abutting the stations (150 meters), the distribution of business size is also roughly the same. 
Table 1: Distribution of business size and sector within each buffer ring

\begin{tabular}{lccccc}
\hline & $\begin{array}{c}\text { Station } \\
\mathbf{1 5 0} \mathbf{~}\end{array}$ & $\begin{array}{c}\text { Station } \\
\mathbf{3 0 5} \mathbf{~ m}\end{array}$ & $\begin{array}{c}\text { Station } \\
\mathbf{4 0 0} \mathbf{~ m}\end{array}$ & $\begin{array}{c}\text { Station } \\
\mathbf{8 0 0} \mathbf{~ m}\end{array}$ & $\begin{array}{c}\text { Control } \\
\mathbf{8 0 0 0} \mathbf{~ m}\end{array}$ \\
\hline Average Employees & 23 & 15 & 11 & 16 & 9 \\
\hline$<5$ employees & $64 \%$ & $76 \%$ & $69 \%$ & $68 \%$ & $75 \%$ \\
\hline $5-10$ employees & $18 \%$ & $10 \%$ & $14 \%$ & $15 \%$ & $12 \%$ \\
\hline $10-100$ employees & $16 \%$ & $12 \%$ & $16 \%$ & $15 \%$ & $12 \%$ \\
\hline Retail & $15 \%$ & $21 \%$ & $25 \%$ & $18 \%$ & $19 \%$ \\
\hline Wholesale & $3 \%$ & $3 \%$ & $5 \%$ & $4 \%$ & $6 \%$ \\
\hline Professional and Technical Services & $38 \%$ & $30 \%$ & $31 \%$ & $37 \%$ & $33 \%$ \\
\hline Food and Entertainment & $16 \%$ & $11 \%$ & $12 \%$ & $12 \%$ & $10 \%$ \\
\hline Other Services & $5 \%$ & $10 \%$ & $12 \%$ & $11 \%$ & $13 \%$ \\
\hline Survived Construction & $55 \%$ & $51 \%$ & $38 \%$ & $60 \%$ & $57 \%$ \\
\hline $\mathrm{N}$ & 261 & 755 & 469 & 2178 & 11544 \\
\hline
\end{tabular}

The primary data source for this analysis is the National Establishment Time-Series database (NETS). The database is maintained by Walls \& Associates using annual snapshots (taken every January) from the Duns Marketing Information file produced by Dun \& Bradstreet. Walls \& Associates generate time-series information on every business, including when it became active, if and/or when it went out of business, any relocation of the business, number of employees, sector, and estimated annual sales. The data can be geocoded by address or latitude and longitude, enabling businesses to be placed along construction corridors.

Kolko et al. (2007) contains the most in-depth assessment of the dataset, its quality, and its limitations. The authors note that the NETS dataset allows for a finer grained analysis than government products such as the Longitudinal Employment and Household Dataset or the Current Employment Survey. In testing the NETS dataset against other available sources for employment counts and birth and death rates, they find that NETS consistently over counts employment as the result of counting owners of multiple establishments (or employees in multiple establishments) with each establishment, but as the error is present throughout the dataset it is unlikely to produce a bias. Schuetz (2015) and Chapple and Jacobus (2008) have used this dataset in research similar to this one.

The data represent the universe of businesses located in Los Angeles County in 1992, the year construction began on the Red Line corridor. The data contain the latitude and longitude of the business's most recent location, its address in 1992 and in 2011, as well as sales, employment, and sector information between 1990 and 2011. The businesses were mapped using the establishment's latitude and longitude provided in the NETS. If the business moved between 1992 and 2011 (defined by changing ZIP code) it was removed from the analysis as it was impossible to know when it moved and thus to tie it to corridor activity. Location variables were calculated using the NETS information and a Red Line shapefile provided publicly on Metro's website.

\section{$5 \quad$ Results}

\subsection{Survival}

The construction period on the Red Line lasted seven years, from 1992 to 1999. Given the long construction time frame and the fact that 60 percent of businesses fail within five years, one would expect 
a majority of businesses to have failed even in the absence of construction (Philips \& Kerchoff, 1989). In fact, a majority of businesses survived in all locations except the band between 305 and 400 meters. (Table 1). Without controlling for confounding variables, the differences in survival rate were not statistically significant.

The first logit model controls for confounding variables and focuses solely on location as the treatment. It assesses the probability of surviving until the opening of the line in 2000 as a factor of business size, sector, and location. The model takes the following form:

$$
\operatorname{Pr}(\text { Failure })=1 /(1+\mathrm{e} \beta \mathrm{X})
$$

where $\mathrm{X}$ is the vector of variables: location, sector, and employment—used as a proxy for firm size; and $\beta$ is the coefficient vector of interest. Each business appears as a single observation and failure is defined as closing before the station opened in 1999.

After accounting for the confounding variables of size and sector using equation 1, the impact of location on survival grows (Table 2). Table 2 shows the odds ratio for each station buffer size with and without controls. Odds ratio values under one reflect a reduced likelihood that the business failed during construction, while values over one increase it. Comparing the location odds ratios show that once size and sector are accounted for, businesses within 305 meters of a station are 55\% more likely to fail, up from $44 \%$ without controls. The strongest effect and best fitting model is for the 400 -meter buffers, consistent with the property value literature. In that model, the businesses within 400 meters of a station are $76 \%$ more likely to fail than businesses farther from the station. When controls are added, the risk increases to $85 \%$ more likely. At the 800 -meter mark, the effect falls considerably, though remains significant, again consistent with the literature. Table 2 also shows that sector in some cases has a larger effect than location. This is consistent with the literature on business survival in which survival varies considerably by sector (Evans, 1987; Bates \& Nucci, 1989). It is riskier to be a retail or wholesale business anywhere than to be near a transit station.

Table 2: Odds ratio estimates from the logistic regression on survival. Ratios $>1$ mean the attribute increases the likelihood of failure, $<1$ reduces.

\begin{tabular}{|c|c|c|c|c|c|c|c|c|}
\hline & \multicolumn{2}{|c|}{$150 \mathrm{~m}$ buffer } & \multicolumn{2}{|c|}{$305 \mathrm{~m}$ buffer } & \multicolumn{2}{|c|}{$400 \mathrm{~m}$ buffer } & \multicolumn{2}{|c|}{$800 \mathrm{~m}$ buffer } \\
\hline & Naive & Controls & Naive & Controls & Naïve & Controls & Naive & Controls \\
\hline Station & 1.167 & $1.302^{*}$ & $1.436^{* * *}$ & $1.545^{* * *}$ & $1.761^{* * *}$ & $1.848^{* * *}$ & $1.093^{*}$ & $1.141^{* * *}$ \\
\hline Rail & 0.884 & $0.85^{* *}$ & $0.786^{* * *}$ & $0.749^{* * *}$ & $0.71^{* * *}$ & $0.683^{* * *}$ & $0.856^{* *}$ & $0.816^{* * *}$ \\
\hline Number of Employees & & $0.996^{* * *}$ & & $0.996^{* * *}$ & & $0.996^{* * *}$ & & $0.996^{* * *}$ \\
\hline Retail & & $1.88^{* * *}$ & & $1.899^{* * *}$ & & $1.892^{* * *}$ & & $1.880^{* * *}$ \\
\hline Wholesale & & $2.115^{* * *}$ & & $2.142^{* * *}$ & & $2.150^{* * *}$ & & $2.120^{* * *}$ \\
\hline Professional Services & & $1.195^{* * *}$ & & $1.202^{* * *}$ & & $1.198^{* * *}$ & & $1.193^{* * *}$ \\
\hline Other Services & & 1.054 & & 1.06 & & 1.056 & & 1.054 \\
\hline Food and Entertainment & & 0.965 & & 0.968 & & 0.961 & & 0.961 \\
\hline AIC & 16870 & 16624 & 16851 & 16599 & 16799 & 16544 & 16867 & 16619 \\
\hline SC & 16892 & 16691 & 16873 & 16666 & 16821 & 16611 & 16889 & 16685 \\
\hline
\end{tabular}

$\mathrm{N}=12,167^{*}<.11^{* *}<.05^{* * *}<.01$

While the model shows considerable effects near stations, there is a real possibility that the effect is not from construction but from inherent location characteristics, a hypothesis encouraged by the 
positive effects of rail corridor location. If businesses along the corridor that are not located near major intersections are thriving, perhaps the cause is a more active market at those intersections. To isolate construction, one must add an element of time. Do those intersections always experience more turnover or was the construction period particularly bad?

A discrete event history model allows one to further untangle the causality by incorporating time as a causal factor. Freeman, Cassola, and Cai (2016) utilize an event history model to explore the decision to move with respect to gentrifying neighborhoods. The method requires panel data, as the unit of observation goes from business to business-year. Once the business closes, it is removed from the dataset. The model is for the probability of closure of business i in year $\mathrm{t}$ :

$$
\log \left(\mathrm{P}_{\mathrm{it}} /\left(1-\mathrm{P}_{\mathrm{it}}\right)\right)=\alpha_{\mathrm{t}}+\beta 1_{\mathrm{xit1}}+\beta 2_{\text {wit2 }} \ldots+\beta \mathrm{k}_{\mathrm{xikt}}
$$

Where $\mathrm{x}$ represents time-unvarying covariates (sector) and w time-varying covariates (employment, construction). Freeman et al. (2016) use an interaction term similar to difference-in-differences to capture their treatment effect, but for this paper, dummy variables are more appropriate. This choice reflects the double treatment applied to the businesses, first construction and then an open rail station. Using an interaction variable for construction would act as though the business environs are the same before and after construction, which is false. Thus, six dummy variables were constructed for each set of buffers, reflecting whether the business was located near a station before, during, and after construction. Those businesses located away from the station during construction are used as the reference group.

Table 3: Discrete event history odds ratios. Ratios $>1$ mean the attribute increases the likelihood of failure, $<1$ reduces.

\begin{tabular}{lcccc}
\hline & $\mathbf{1 5 0} \mathbf{~}$ buffer & $\mathbf{3 0 5} \mathbf{~}$ buffer & $\mathbf{4 0 0} \mathbf{~}$ buffer & $\mathbf{8 0 0} \mathbf{~}$ buffer \\
\hline Near station before & 1.195 & 1.011 & 1.159 & 0.951 \\
\hline Not near station before & $0.942^{*}$ & 0.957 & 0.963 & 0.962 \\
\hline Near station during & 1.056 & $1.282^{* * *}$ & $1.46^{* * *}$ & $1.065^{*}$ \\
\hline Near station after & $0.618^{* *}$ & $0.613^{* * *}$ & $0.678^{* * *}$ & $0.501^{* * *}$ \\
\hline Not near station after & $0.447^{* * *}$ & $0.448^{* * *}$ & $0.45^{* * *}$ & $0.442^{* * *}$ \\
\hline Number of Employees & $0.998^{* * *}$ & $0.998^{* * *}$ & $0.998^{* * *}$ & $0.998^{* * *}$ \\
\hline Retail & $1.513^{* * *}$ & $1.516^{* * *}$ & $1.512^{* * *}$ & $1.512^{* * *}$ \\
\hline Wholesale & $1.658^{* * *}$ & $1.676^{* * *}$ & $1.690^{* * *}$ & $1.662^{* * *}$ \\
\hline Professional Services & $1.184^{* * *}$ & $1.190^{* * *}$ & $1.192^{* * *}$ & $1.184^{* * *}$ \\
\hline Other Services & 1.034 & 1.040 & 1.042 & 1.035 \\
\hline Food and Entertainment & 0.948 & 0.949 & 0.947 & 0.946 \\
\hline AIC & 52334 & 52311 & 52254 & 52330 \\
\hline SC & 52448 & 52426 & 52368 & 52445 \\
\hline
\end{tabular}

$\mathrm{N}=101,846^{*}=.1^{* *}=.05^{* * *}=.01$

Table 3 gives the discrete event history results. All models were run with controls and robust standard error. Comparing the "on during" results to the odds ratios in Table 2 shows that construction has a smaller impact now that the model controls for time and location. Businesses within 305 meters of the station are only $28 \%$ more likely to fail than those farther, down from $55 \%$, for example. As with the basic logistic model, the 400-meter buffer sees the strongest effect in the basic logistic model, with businesses within 400 meters of a station being $46 \%$ more likely to fail, down from $85 \%$ before.

The survival models show that station construction has a negative impact on firm survival, but the mechanism needs to be isolated. The alignment with the property value literature on the 400-meter buffer suggests that changing real estate values and their trickle down effects in rents might be to blame, but there is also the possibility of lost revenue. 


\subsection{Revenue}

To test the revenue loss question, the revenue specification utilizes difference-in-differences for causal inference. Annual sales for each business are averaged into two periods, 1990-1992 and 1993-1999, representing the pre-construction and during construction phases. Pooling tackles some of the serial correlation issues with difference-in-differences, as noted in Bertrand, Duflo, and Mullainathan (2004). The model is run with both annual sales and the log of annual sales as the dependent variable. The log minimizes the impact of outlier businesses that may have very high sales. Comparing the results for the two models can assist in identifying where effects may be driven by outlier businesses.

The difference-in-differences equation is an ordinary least squares regression with time and location fixed effects:

$$
\begin{aligned}
\text { Sales }= & \beta_{1} \text { period }+\beta_{2} \text { rail } 200+\beta_{3} \text { sta1000 }+\beta_{4}\left(\text { period }^{\star} \text { rail } 200\right)+\beta_{5}\left(\text { period }^{*} \text { sta } 1000\right)+ \\
& \beta_{x}(\text { employment, sector. } .)
\end{aligned}
$$

The coefficients of interests are $\beta 4$ and $\beta 5$, the difference-in-difference estimators for location on the rail corridor or near a station. They should have a negative sign if construction negatively impacts revenue over and above the influence of other economic effects that change over time, like the 1992 civil unrest that affected local businesses or the 1994 Northridge earthquake (which would be captured in $\beta 1$ ) or other location effects captured in $\beta 2$ and $\beta 3$.

A key assumption for difference-in-differences is that parallel trends precede the intervention. Figure 3 below demonstrates that, given the available data, the trends of mean sales are roughly parallel between 1990 and 1992, the years preceding construction. The 150-meter buffer does have a slightly rising trend.

\$3 Million

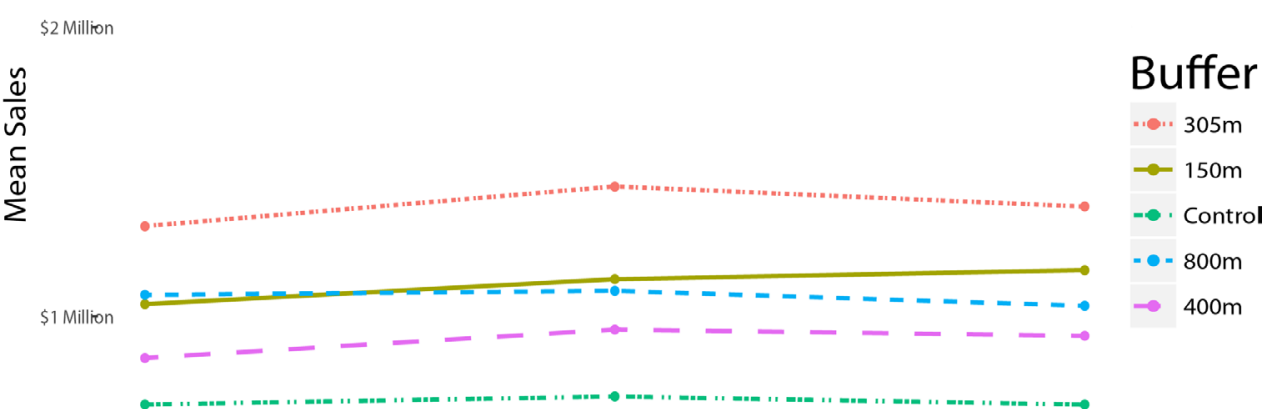

0 .

1990

Figure 3: Sales trends by buffer, 1990-1992
1991

Year 
Table 4: Difference in Differences results, logsales

\begin{tabular}{lcccc}
\hline & $\mathbf{1 5 0} \mathbf{~ m}$ buffer & $\mathbf{3 0 5} \mathbf{~ m ~ b u f f e r}$ & $\mathbf{4 0 0} \mathbf{~ m}$ buffer & $\mathbf{8 0 0} \mathbf{~ m}$ buffer \\
\hline Rail & 0.0188 & 0.02 & 0.0099 & -0.059 \\
\hline Station & 0.115 & 0.052 & 0.069 & $0.14^{* * *}$ \\
\hline Period & $-0.066^{* * *}$ & $-0.066^{* * *}$ & $-0.066^{* * *}$ & $-0.067^{* * *}$ \\
\hline period*rail & 5310 & 0.0053 & 0.002 & -0.006 \\
\hline period*station $^{\text {Adjusted Rsquared }}$ & -0.036 & -0.021 & -0.013 & 0.003 \\
\hline
\end{tabular}

The $\mathrm{DiD}$ results for the log of sales show no significance in the interaction terms (Table 4). There is a significant negative decline between periods. There is also an increase in revenue for businesses 800 meters from stations, but this reflects location differences rather than construction as the interaction variable is not significant. The station interaction terms do have the expected sign and decrease in intensity with distance from construction, but they are not significant. All models were run with size and sector controls.

Table 5: Difference-in-differences results, sales

\begin{tabular}{lcccc}
\hline & $\mathbf{1 5 0} \mathbf{~}$ buffer & $\mathbf{3 0 5} \mathbf{~ m}$ buffer & $\mathbf{4 0 0} \mathbf{~ m}$ buffer & $\mathbf{8 0 0} \mathbf{~ m}$ buffer \\
\hline Rail & $\$ 137,919^{*}$ & $\$ 11,448$ & $\$ 28,376$ & $\$ 21,306$ \\
\hline Station & $-\$ 393,997^{* * *}$ & $\$ 113,338$ & $\$ 67,833$ & $\$ 53,317$ \\
\hline Period & $-\$ 17,858.60$ & $-\$ 12,825$ & $-\$ 12,698$ & $-\$ 1,560$ \\
\hline period*rail & $\$ 5,310$ & $\$ 52,931$ & $\$ 27,362$ & $\$ 52,227$ \\
\hline period*station & $-\$ 88,208$ & $-\$ 152,779$ & $-\$ 85,230$ & $-\$ 89,386$ \\
\hline Adjusted Rsquared & 0.4635 & 0.4632 & 0.4632 & 0.4632 \\
\hline
\end{tabular}

Like the log results, the sales results show no significant error term, though the station is significant and negative for businesses within 150 meters of the station. The greatest revenue decrease for a station interaction term is at 305 meters, but again, there is no significance. The revenue findings suggest that while revenue loss may be occurring, it is not the main mechanism by which businesses are failing.

\section{Discussion}

Just as local residents are calling to be protected from displacement, transit builders should be aware of their projects' tendency to displace local businesses as well. Given the results of the discrete-time event history model, station construction appears to increase the risk of business failure by $46 \%$ for businesses within 400 meters of a station, though station location always appears to be somewhat riskier than location away from a station.

The results show a negative impact on business survival from station construction, but the mechanism(s) remain unclear. While business owners report lost revenue from construction activity (e.g., Hernandez, 2014), the results from the revenue analysis are insignificant, suggesting that lost revenue is not the primary mechanism through which business failure occurs. Given the negative effects of transit construction on business survival, the key takeaways from this research are 1) that more research is needed to identify the mechanisms through which transit construction leads to business failure and 2) that the research provides strong support for the need for construction mitigation programs.

The leading candidate for an alternate mechanism is transit construction spurring turnover in prop- 
erty ownership and lease agreements. Transit access has been shown to increase commercial property values, which can often affect businesses in the form of increased rents. Sales may or may not increase, depending on the relationship of the business's clientele to the new populations accessing the location and on the business's capacity for growth. Some businesses may be able to increase sales and adapt to new consumers, while others may sell a more specialized product or lack the capital for growth. Those businesses that do not grow may be unable to meet the new rent and close, or landlords may assume that businesses will not be able to keep up and choose not to renew. News stories about the construction of the Crenshaw line in Los Angeles, which told of landlords choosing not to renew leases, provide some support for such a mechanism, as does Blair Ruble's qualitative investigation of the U Street corridor in Washington, DC (Merina, 2016; Kaplan, 2103; Ruble, 2010).

The turnover mechanism, while not unique to rail, could affect business survival rates without appearing in the sales data. Moreover, they could explain the higher risk profile of station locations both before and after construction. Station locations are placed at points of high demand, which would make them more commercially valuable and therefore potentially more prone to volatility in business tenancy as landlords seek to maximize profits from rent. Property transactions can also rise as speculators hope to profit off the increasing land values, leading to instability in rents and lease arrangements.

In addition to the insignificance of the revenue model and the higher riskiness of station location overall, the heightened turnover hypothesis is concurrent with findings in the residential gentrification literature that renters are more at risk than owners (Lees, Slater, \& Wyly, 2008). Further research includes examining the survival rates of businesses that own rather than rent their space to see how tenure compares to the more common factors of employment and sector. Exploring the effect of tenure on survival would require data that is currently unavailable. The first step for community advocates and transit agencies concerned with business displacement would be to begin tracking not only revenue loss, as the Metropolitan Council did in Minneapolis-St. Paul, but also whether the businesses rent and own. Much like with residential gentrification, benefits may accrue to those who own, while those who rent are displaced.

Regardless of the mechanism, the negative effects of transit construction on survival argue that the loan and technical assistance programs run by agencies like TriMet in Portland and the Met Council in Minnesota should become standard practice. The insignificance of the revenue mechanism demonstrates that the focus should be on supporting businesses in retooling to meet a new demand in addition to mitigating construction nuisance. Where those programs are insufficient due to extremely high demand or niche businesses, programs like San Francisco's Legacy business project can be adapted to protect those businesses that provide a larger benefit to the community (City and County of San Francisco Planning Department, n.d.). Such programs allow the transit planner to resolve the dilemma of transformation and improvement by allowing existing businesses to transform alongside the corridor, benefiting both transit users and the broader community. 


\section{References}

Agnew, S., Baum, P., Croaston, M., Janzen, A., Jerabek, E., Jorgenson, B., Senn, A., \& Yang, J. (2010). The potential impact of central corridor LRT on existing University Avenue businesses. Minneapolis, MN: Humphrey Institute, University of Minnesota.

Bates, T. (1990). Entrepreneur human capital inputs and small business longevity. The Review of Economics and Statistics, 72, 551-559. doi:10.2307/2109594

Bates, T., \& Nucci, A. (1989). An analysis of small business size and rate of discontinuance. Journal of Small Business Management, 27, 1.

Benjamin, J. D., Boyle, G. W., \& Sirmans, C. F. (1990). Retail leasing: The determinants of shopping center rents. AREUEA Journal, 18, 302.

Bertrand, M., Duflo, E., \& Mullainathan, S. (2004). How much should we trust differences-in-differences estimates? The Quarterly Journal of Economics, 119, 249-275.

Cervero, R., \& Duncan, M. (2002). Land value impacts of rail transit services in Los Angeles County. Washington, DC: National Association of Realtors Urban Land Institute.

Chapple, K., \& Jacobus, R. (2008). Retail trade as a route to neighborhood revitalization. In Urban and regional policy and its effects. Washington, DC: Brookings Institution Press.

City and County of San Francisco Planning Department. (n.d.) Legacy Business Registry. Retrieved from City and County of San Francisco Planning Department website: http://sf-planning.org/legacy-business-registry.

De Solminihac, H. E., \& Harrison, R. (1993). Analyzing effects of highway rehabilitation on businesses. Transportation Research Record, 1397, 137-143.

Debrezion, G., Pels, E., \& Rietveld, P. (2007). The impact of railway stations on residential and commercial property value: A meta-analysis. Journal of Real Estate Finance and Economics, 35, 161-180. doi:10.1007/s11146-007-9032-z

Dominie, W. (2012). Is just growth smarter growth? The effects of gentrification on transit ridership and driving in Los Angeles' transit station area neighborhoods. Los Angeles: University of California, Los Angeles.

Drew, J. E. (1996). Memorandum of understanding between MTA and CRA.

Evans, D. S. (1987). The relationship between firm growth, size, and age: Estimates for 100 manufacturing industries. The Journal of Industrial Economics, 35, 567-581. doi:10.2307/2098588

Everett, J., \& Watson, J. (1998). Small business failure and external risk factors. Small Business Economics, 11, 371-390.

Fan, Y., \& Guthrie, A. (2013). Doing business around transit corridors. Transportation Research Record, 2351, 142-152. doi:10.3141/2351-16

Fejarang, R. A. (1993). Impact on property values: A study of the Los Angeles Metro Rail. Papaer presented at the Public Transport Planning and Operations Proceedings held at the European Transport, Highways, and Planning 21st Summer Annual Meeting, Manchester, England, Sept. 13-17.

Freeman, L., Cassola, A., \& Cai, T. (2016). Displacement and gentrification in England and Wales: A quasi-experimental approach. Urban Studies, 53, 2797-2814. doi:10.1177/0042098015598120

Fujioka, G. (2011). Transit-oriented development and communities of color: A field report. Retrieved from Planners Network website: http://www.plannersnetwork.org/2011/01/transit-oriented-development-and-communities-of-color-a-field-report/

Harrison, R., \& Waldman, B. (1998). Mitigating the adverse impacts of the Dallas North Central Expressway construction on businesses. Transportation Research Record, 1632, 51-58. doi:10.3141/1632-06

Headd, B. (2003). Redefining business success: Distinguishing between closure and failure. Small 
Business Economics, 21, 51-61.

Hernandez, M. (2014). Metro Crenshaw construction hurting local businesses. Retrieved from ABC7 Los Angeles website: http://abc7.com/255356/

Higgins, C. D., \& Kanaroglou, P. S. (2016). Forty years of modelling rapid transit's land value uplift in North America: Moving beyond the tip of the iceberg. Transport Reviews, 36, 610-634. doi:10.108 0/01441647.2016.1174748

Houston Tomorrow. (2006). Impact of light rail construction on existing businesses: A survey of six cities with recent light rail construction projects. Retrieved from Houston Tomorrow website: http://www. gulfcoastinstitute.org/university/LightRail_ImpactOnBusinessDC.pdf

Kahn, M. E. (2007). Gentrification trends in new transit-oriented communities: Evidence from 14 Cities that expanded and built rail transit systems. Real Estate Economics, 35, 155-182.

Kaplan, E. A. (2013). Leimert Park: Where does it go from here? Retrieved from KCET website: https:// www.kcet.org/shows/departures/leimert-park-where-does-it-go-from-here

Kolko, J. D., Neumark, D., \& Lefebvre-Hoang, I. (2007). Business location decisions and employment dynamics in California. San Francisco: Public Policy Institute of California.

Krieg, A. (2009). The impact of light rail construction on neighborhood business activity in the Rainier Valley, Seattle, Washington. Gainesville, FL: University of Florida.

Lees, L., Slater, T., \& Wyly, E. (2008). Gentrification. New York: Routledge/Taylor \& Francis Group.

Lin, J. (2002). Gentrification and transit in northwest Chicago. Transportation Quarterly, 56, 175.

Main, B. (1989). Restaurant leases: Like money in the bank. Cornell Hotel and Restaurant Administration Quarterly, 30, 83-89.

Mathur, S., \& Smith, A. (2012). A decision-support framework for using value capture to fund public transit: Lessons from project-specific analyses. San Jose, CA: San Jose State University, Lucas Graduate School of Business, Mineta Transportation Institute.

Meltzer, R., \& Schuetz, J. (2012). Bodegas or bagel shops? Neighborhood differences in retail and household services. Economic Development Quarterly, 26, 73-94. doi:10.1177/0891242411430328

Merina, D. (2016). Crenshaw shopsweigh challenges, promise of new train line. Take Two [radio program], KPCC news radio. Retrieved from http://www.scpr.org/programs/take-two/2016/02/04/46186/ crenshaw-shops-weigh-challenges-promise-of-new-tra/

Metropolitan Council, Federal Transit Administration. (2013). Central corridor supplemental final EIS construction-related potential impacts on business revenue. Retrieved from Metropolitan Council website: https://metrocouncil.org/Transportation/Projects/Current-Projects/Central-Corridor/ Publications-And-Resources/Environmental/SFEIS/Central-Corridor-Supplemental-Final-EISConstr-(1).aspx

Mohammad, S. I., Graham, D. J., \& Melo, P. C. (2017). The effect of the Dubai Metro on the value of residential and commercial properties. Journal of Transport and Land Use, 10, 263-290. doi:10.5198/ jtlu.2015.750

Mohammad, S. I., Graham, D. J., Melo, P. C., \& Anderson, R. J. (2013). A meta-analysis of the impact of rail projects on land and property values. Transportation Research Part A: Policy and Practice, 50, 158-170. doi:10.1016/j.tra.2013.01.013

Nelson, A. C., Eskic, D., Hamidi, S., Petheram, S. J., Ewing, R., \& Liu, J. H., (2015). Office rent premiums with respect to light rail transit stations: Case study of Dallas, Texas, with implications for planning of transit-oriented development. Transportation Research Record, 2500, 110-115. doi:10.3141/2500-13

Oldenburg, R. (1999). The great good place: Cafes, coffee shops, bookstores, bars, hair salons, and other hangouts at the heart of a community, 3rd edition. New York: Marlowe \& Company. 
Phillips, B. D., \& Kirchhoff, B. A. (1989). Formation, growth and survival; Small firm dynamics in the U.S. economy. Small Business Economics, 1, 65-74. doi:10.1007/BF00389917

Pollack, S., Bluestone, B., \& Billingham, C. (2010). Maintaining diversity in Americas transit-rich neighborhoods. Boston: Dukakis Center for Urban and Regional Policy, Northeastern University.

Richardson, A. (2014). A comparison study of measures to mitigate loss of business revenue during major construction projects. Journal of Affordable Housing and Community Development Law, 22, 267-298.

Ruble, B. A. (2010). Washington's U Street: A biography, 1 edition. Baltimore, MD: Johns Hopkins University Press.

Schuetz, J. (2015). Do rail transit stations encourage neighborhood retail activity? Urban Studies, 52, 2699-2723. doi:10.1177/0042098014549128

Taylor, B. D., Kim, E. J., \& Gahbauer, J. E. (2009). The thin Red Line: A case study of political influence on transportation planning practice. Journal of Planning Education and Research, 29, 173-193. doi:10.1177/0739456X09344718

Tigan, J. (2014). Central corridor funders collaborative-Central corridor key outcomes, 2014 indicators report. Retrieved from https://www.wilder.org/Wilder-Research/Publications/Studies/Central\%20 Corridor\%20Funders $\% 20$ Collaborative/Central\%20Corridor\%20Key\%20Outcomes, $\% 20$ 2014\%20Indicators\%20Report,\%20Full\%20Report.pdf

Weinstein, B. L., \& Clower, T. L. (1999). The initial economic impacts of the DART LRT system. Denton, TX: University of North Texas Center for Economic Development and Research.

Young, R., Wolffing, C., \& Tomasini, M. (2005). Highway construction impacts on Wyoming businesses. Transportation Research Record, 1924, 94-95. doi:10.3141/1924-12

Zukin, S., Trujillo, V., Frase, P., Jackson, D., Recuber, T., \& Walker, A. (2009). New retail capital and neighborhood change: Boutiques and gentrification in New York City. City and Community, 8, 47-64. doi:10.1111/j.1540-6040.2009.01269.x 